\title{
Analysis of plant assortment in the greenhouse complex of vinnytsia National Agrarian University as a key component of student training
}

\author{
V. V. Monarkh, M. V. Matusiak \\ Candidate of Agricultural Sciences, Senior Lecturer of the Department of Forestry, Landscape \\ Management, Horticulture and Viniculture, Vinnytsia National Agrarian University (Soniachna Str. 3, \\ Vinnytsia, 21008, Ukraine
}

E-mail: monarhinya@ukr.net; mikhailo1988@gmail.com

Received: 03.02.2020 Accepted 03.03.2020

It is proved that the greenhouse of Podillia Botanical Garden of Vinnytsia National Agrarian University is the place intended for landscaping having over 90 species of exotic plants as well as water devices and small architectural forms that are represented on a limited area. The main purpose of the greenhouse is not only the aesthetic satisfaction of guests and residents of the city and outdoor activities in any season of the year, but also the reproduction and introduction of plant species from other climatic zones. For the first time, a modern assessment of the assortment of greenhouse plants of Podillya Botanical Garden of VNAU has been conducted, according to which there are 44 families, 88 genera and 94 plant species in the greenhouse. It is found that the main components of the greenhouse are the species belonging to different families and differing in the requirements necessary for their growth and development. The assortment of species presented in the greenhouse is extremely wide. It is established that plants belong to different climatic zones according to their requirements for the habitat. Therefore, to ensure their ornamentality and excellent growth in the greenhouse, it is necessary to provide adequate conditions. It has been investigated that plants of different natural habitats are randomly arranged in the greenhouse without a certain order or systematization. In the greenhouse of the Botanical Garden, species of introduced plants differ by their respond to the temperature acceptable for their normal growth and development, so they should be placed in groups or collections, e.g. a plant zone of Tropics, a plant zone of Subtropics, a plant zone of dry Subtropics, a plant zone of the Mediterranean, and a plant zone of Asia. Considering a small number of the representatives of dry Subtropics in the greenhouse of the Botanical Garden, the collection of succulents must be replenished and florarium and cactusarium must be established.

Key words: Winter garden; Introduced species; Habitat; Inventory; Object

\section{Introduction}

In the territory of Vinnytsia region, along with famous tourist architectural monuments, there is a research and educational institution that has got a collection of trees and shrubs from different climatic zones, a place of cultivation, preservation and acclimatization of plant species that are perspective for the creation of green plantations to ensure city landscaping. This facility is Podillia Botanical Garden located on the territory of Vinnytsia National Agrarian University Monarkh, 2019.

The greenhouse located in the Botanical Garden is the place intended for landscaping. More than 90 species of exotic plants as well as an ornamental pond are represented on its limited area. The main purpose of the greenhouse is not only the aesthetic satisfaction of guests and residents of the city and outdoor activities in any season of the year, but also the reproduction and introduction of plant species of other climatic zones Cherniak, 2018.

\section{Materials and Methods}

The purpose of our work was to analyze the assortment of greenhouse plants in Podillia Botanical Garden. To achieve this goal, the following objectives were set:

- to carry out a taxonomic analysis of the plant assortment in the greenhouse of Podillia Botanical Garden;

- to distinguish available plant assortment according to the natural habitat of plants;

- to group greenhouse plants by climatic zones;

- to provide guidelines for improving the location of plants in the greenhouse.

Practical value of the results obtained. Depending on the plant respond to the temperature regime and its typical climatic zones, it is recommended to place plants that grow in the greenhouse of the Botanical garden in groups or collections, e.g. plants of Tropics, Subtropics, dry Subtropics, plants of the Mediterranean, plants of Asia. Considering a small number of species and genera having their natural habitat in dry Subtropics, the collection of succulents must be replenished in the greenhouse of the Botanical Garden and florarium and cactusarium must be established.

Kryzhanivska (2018) argues that a winter garden is the environment created artificially with the use of structural elements of landscape, floral, and phytodesign and it is a place where people may have a rest depending on its nature. The author notes that it 
is the green planting that plays a major role in the formation of winter gardens. In addition, plants need not be alive or natural, though such objects can be formed using artificial flowers that are much cheaper to buy and keep than live plant compositions Kryzhanivska, 2015.

According to Kucheriavyi (2017), the composition organization of the winter garden is expressed in the placement of plant communities, aquatic devices, geoplastics in a certain space with the identification of its stylistics - ornamental landscaping or architectural landscaping Ermolova (2010) argues that ornamental landscaping stylistics characterizes creation of the environment with imitation of the natural landscape, e.g. desert, steppe, forest, mountainous landscape, etc. Arrangement of the spatial and object environment, in accordance with architectural landscape stylistics, usually involves the use of the symbols of a particular country, e.g. Japanese, Chinese, English ones, etc., as well as adhering to the styles of architecture, the most popular of which are baroque, classicism, modernism and many others Ermolova, 2010.

Each winter garden created is unique in its architectural and artistic design. When creating a composition, knowledge of the composition is compulsory as well as the adherence to all the rules for building such objects. Roy (2019) recommends to follow the techniques of natural landscape imitation in order to achieve the artistic expressiveness of the garden. A small winter garden may remind a viewer or a visitor of the "mid-forest", "wet tropics", or "micro-landscape of the desert with cacti" Roy, 2019.

Availability of certain structural elements in the winter garden directly depends on its main functional purpose. What institution will it be located in? What is the age category of its visitors (children, youth, adults or retirees)? These are the basic questions to be answered before you start to design a winter garden, since the things of the winter garden that are interesting for the children may not impress the adults Monarkh, 2019: Votinov, 2011: Mazur, 2019: Neyko, 2019.

\section{Results and Discussion}

Plant species that belong to different families are the components of any greenhouse. Considering the fact that plants growing indoors are brought from different countries, the temperature regime for each species is different depending on the natural area of origin. Plants of different climatic zones should be placed separately. It is compulsory to monitor the microclimate of the environment to ensure normal growth of the introduced species. Having evaluated the assortment of the object researched, it has been found that 94 plant species grow in the greenhouse of Podillia Botanical Garden (Figures 1 and 2).

Figure 1. Exotic greenhouse plants.

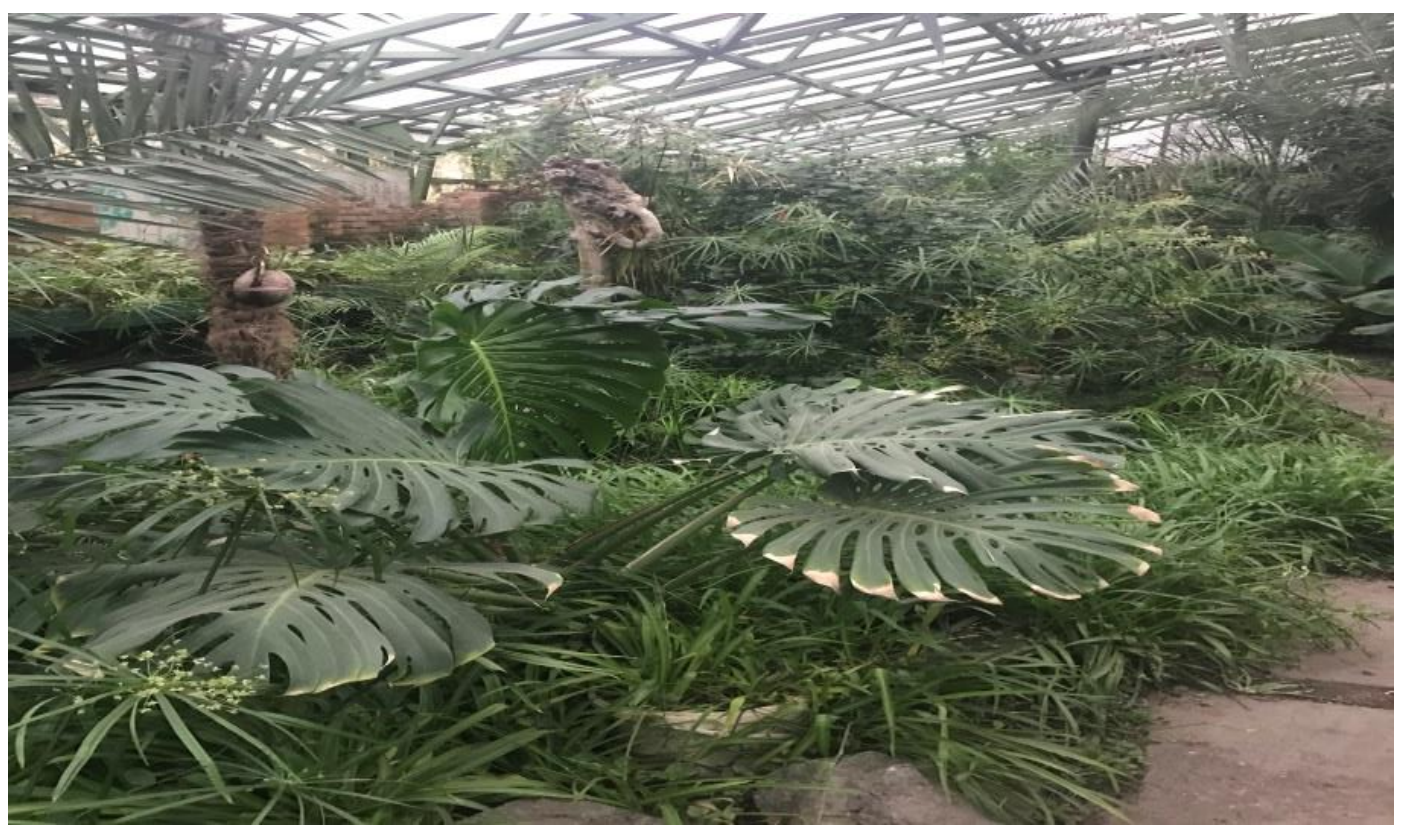

Results of the research of the greenhouse plant collection are presented in Table 1. The Araceae family is characterized by the largest number of genera, hence among 7 genera the following species are available: Philodendron adamantinum Mart. ex Schott, Colocasia esculenta var. fontanesii, Scindapsus, Aglaonema commutatum, Zantedeschia aethiopica, Monstera obliqua, Spathiphyllum floribundum. The Asparagaceae family is represented by 6 genera. Among the species growing in the greenhouse the following ones are available: Aspidistra elatior Variegata, Asparagus officinalis L., Agave americana L., Yucca filamentosa, Dracaena draco, Chlorophytum comosum.

The vast majority of families are represented in the greenhouse with only one genus, e.g. Begoniaceae - Begonia L., CornaceaeAucuba, Ebenaceae - Diospyros, Tiliaceae - Sparmannia, Buxaceae - Buxus, Asphodelacea - Aloe, Musaceae - Musa, Davalliaceae - Nephrolépis, Orchidaceae) - Cattleya, Oleaceae - Ligustrum, Piperaceae - Peperomia, Paulowniaceae - Paulownia, Rosaceae Rosa, Lamiaceae - Coleus, Strelitziaceae - Strelitzia, Lythraceae-Granatum, Liliaceae-Ruscus, Myrtaceae - Callistemon, Fabaceae - Caesalpinia, Balsaminaceae - Impatiens. In total, there are 44 families, 88 genera and 94 species in the greenhouse (Figure 3). Distribution of the assortment of greenhouse plants according to the natural habitat is presented below (Table 2).

It has been found that plants of different natural habitats are randomly arranged in the greenhouse without a certain order or systematization. In the greenhouse of the Botanical Garden, species of introduced plants differ by their respond to the temperature acceptable for their normal growth and development, so they should be placed in groups or collections (Figures 4 and 5 ), e.g. a plant zone of Tropics, a plant zone of Subtropics, a plant zone of dry Subtropics, a plant zone of the Mediterranean, and a plant zone of Asia (Table 3). 
Table 1. Results of evaluation of the assortment of the greenhouse plant collection.

\begin{tabular}{|c|c|c|c|}
\hline No & Name of the family & $\begin{array}{l}\text { Number of } \\
\text { genera }\end{array}$ & Number of species \\
\hline 1 & Malvaceae & 2 & 2 \\
\hline 2 & Asparagaceae & 6 & 6 \\
\hline 3 & Begoniaceae & 1 & 1 \\
\hline 4 & Cornaceae & 1 & 1 \\
\hline 5 & Araliaceae & 2 & 2 \\
\hline 6 & Rutaceae & 4 & 4 \\
\hline 7 & Ebenaceae & 1 & 1 \\
\hline 8 & Tiliaceae & 1 & 1 \\
\hline 9 & Buxaceae & 1 & 1 \\
\hline 10 & Asphodelacea & 1 & 1 \\
\hline 11 & Arecaceae & 2 & 2 \\
\hline 12 & Araceae & 7 & 7 \\
\hline 13 & Moraceae & 1 & 3 \\
\hline 14 & Geraniaceae & 2 & 3 \\
\hline 15 & Davalliaceae & 1 & 1 \\
\hline 16 & Lamiaceae & 2 & 2 \\
\hline 17 & Amaryllidaceae & 5 & 5 \\
\hline 18 & Agavaceae & 2 & 2 \\
\hline 19 & Orchidaceae & 1 & 1 \\
\hline 20 & Oleaceae & 1 & 1 \\
\hline 21 & Urticaceae & 2 & 2 \\
\hline 22 & Apocynaceae & 2 & 2 \\
\hline 23 & Acanthaceae & 3 & 3 \\
\hline 24 & Cupressaceae & 2 & 2 \\
\hline 25 & Musaceae & 1 & 1 \\
\hline 26 & Lauraceae & 2 & 2 \\
\hline 27 & Bignoniaceae & 3 & 3 \\
\hline 28 & Commelinaceae & 5 & 6 \\
\hline 29 & Piperaceae & 1 & 1 \\
\hline 30 & Paulowniaceae & 1 & 1 \\
\hline 31 & Rosaceae & 1 & 1 \\
\hline 32 & Bromeliaceae & 4 & 4 \\
\hline 33 & Cactaceae & 2 & 2 \\
\hline 34 & Lamiaceae & 1 & 1 \\
\hline 35 & Strelitziaceae & 1 & 1 \\
\hline 36 & Crassulaceae & 3 & 3 \\
\hline 37 & Lythraceae & 1 & 1 \\
\hline 38 & Xanthorrhoeaceae & 2 & 2 \\
\hline 39 & Liliaceae & 1 & 1 \\
\hline 40 & Myrtaceae & 1 & 1 \\
\hline 41 & Euphorbiaceae & 2 & 2 \\
\hline 42 & Fabaceae & 1 & 1 \\
\hline 43 & Balsaminaceae & 1 & 1 \\
\hline \multirow[t]{2}{*}{44} & Vitáceae & 1 & 3 \\
\hline & Total & 88 & 94 \\
\hline
\end{tabular}

Figure 2. Greenhouse of Podillia Botanical Garden.

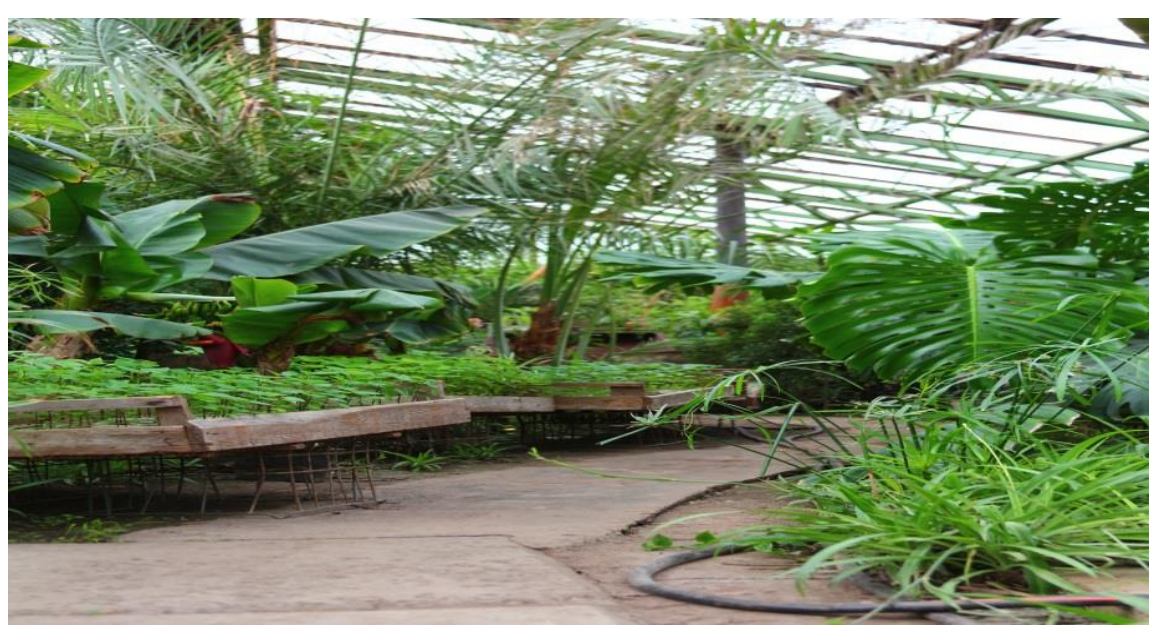


Figure 3. An ornamental pond of the greenhouse.

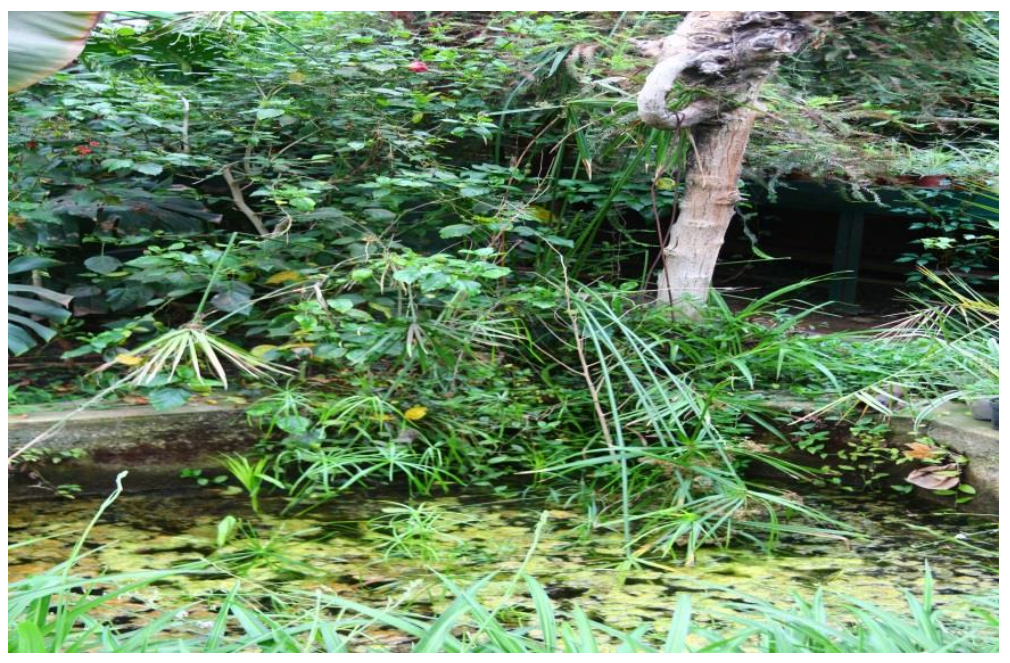

Table 2. Types of greenhouse plants with the natural habitat indicated.

\begin{tabular}{|c|c|c|}
\hline No & Name of species (in Latin) & Natural area of origin \\
\hline 1 & Abutilon sellovianum Rgl. & $\begin{array}{l}\text { Tropics and subtropics of both } \\
\text { hemispheres }\end{array}$ \\
\hline 2 & Aspidistra elatior Variegata & Forests of South China and Japan \\
\hline 3 & Asparagus officinalis $L$. & Central America, Australia \\
\hline 4 & Begonia semperflorens & Latin America, Mexico, Shri-Lanka, Africa \\
\hline 5 & Aucuba japonica & East Asia, Japan \\
\hline 6 & Fatsia japonica & Japan, New Zealand \\
\hline 7 & Fortunella hindsii & Asia Pacific region \\
\hline 8 & Citrus reticulata & South of China, East Asia \\
\hline 9 & Citrus sinensis & Europe, the Caucasus \\
\hline 10 & Citrus $x$ limon & Europe, America \\
\hline 11 & Diospyros lotus & Europe, America, Australia \\
\hline 12 & Hibiscus syriacus & Subtropics and tropics \\
\hline 13 & Sparmannia africana & Madagascar, South Africa \\
\hline 14 & Buxus sempervirens $L$. & Africa, Madagascar, Mexico \\
\hline 15 & Aloe arborescens & Africa, Madagascar, the island of Socotra \\
\hline 16 & Agave americana $L$. & North and Central America \\
\hline 17 & Yucca filamentosa & Florida, the USA, Mexico \\
\hline 18 & Trachycarpus fortunei. & China, Japan, Myanmar and India \\
\hline 19 & Phoenix canariensis & $\begin{array}{l}\text { Greece, the island of Crete, Canary } \\
\text { Islands }\end{array}$ \\
\hline 20 & Dracaena draco & South-East Asia, Africa \\
\hline 21 & Philodendron adamantinum Mart. ex Schott & Latin America, Mexico, Australia \\
\hline 22 & Ficus elastica & Africa, the Mediterranean \\
\hline 23 & Ficus benjamina & India, China, Philippines \\
\hline 24 & Ficus carica & Mediterranean, Middle East \\
\hline 25 & Chlorophytum comosum & $\begin{array}{l}\text { South America, Africa, Madagascar, Asia } \\
\text { and Australia }\end{array}$ \\
\hline 26 & Pelargonium zonale & East Africa, Middle East \\
\hline 27 & Pelargonium grandiflorum & Middle East, the south of Turkey and Iraq \\
\hline 28 & Pelargonium graveolens & $\begin{array}{l}\text { The temperate zone of the Northern } \\
\text { Hemisphere }\end{array}$ \\
\hline 29 & Nephrolepis cordifolia (L.) Pres/ & Asia, America, Australia \\
\hline 30 & Plectranthus fruticosus & Tropics of Africa, Asia, Australia \\
\hline 31 & Zephyranthes lindleyana & East Africa \\
\hline $\begin{array}{l}32 \\
33\end{array}$ & $\begin{array}{l}\text { Sansevieria trifasciata } \\
\text { Cattleya }\end{array}$ & $\begin{array}{l}\text { Africa, Madagascar and Asia } \\
\text { Tropical forests }\end{array}$ \\
\hline 34 & Hedera caucasigena & Europe \\
\hline 35 & Ligustrum vulgare & Moderate and subtropical forests \\
\hline 36 & Pilea cadierei Gagnep. & Tropical forests throughout the Earth \\
\hline 37 & Rosmarinus officinalis & Western Mediterranean \\
\hline 38 & Vinca minor $L$. & Countries of South Europe \\
\hline 39 & Justicia adhatoda & Mexico \\
\hline 40 & Cryptomeria japonica & Japan, China \\
\hline 41 & Musa basjoo & India, Japan \\
\hline 42 & (Laurus nobilis & The Mediterranean \\
\hline 43 & (Jacaranda mimosifolia & Tropics of Brazil \\
\hline
\end{tabular}




\begin{tabular}{|c|c|}
\hline (Tradescantia tricolor & Mexico, Central America \\
\hline (Peperomia magnoliaefolia & Asia and America \\
\hline Taxodium distichum & Northern and Southern Hemisphere \\
\hline Paulownia tomentosa & Far East, East Asia \\
\hline Rosa bengalensis & All Europe \\
\hline Billbergia pyramidalis & Brazil, Central America \\
\hline Vriesea splendens & Central and South America \\
\hline Guzmania & Venezuela, Brazil \\
\hline Amaryllis belladonna & $\begin{array}{l}\text { Cape Province of the Republic of South } \\
\text { Africa, Australia }\end{array}$ \\
\hline Clivia miniata & South Africa \\
\hline Radermachera chinensis & China \\
\hline Nerium oleander & The Mediterranean \\
\hline Crinum asiaticum & Asia \\
\hline Coleus blumei & Asia and Africa \\
\hline Colocasia esculenta var. fontanesii & Tropical forests of Burma, Himalayas \\
\hline Strelitzia reginae & South Africa \\
\hline Echeveria stolonifera & Mexico \\
\hline Scindapsus & Tropical forests of East Asia \\
\hline Ruellia tuberosa $L$. & East Asia \\
\hline Ananas comosus & South America \\
\hline Persēa americāna & Europe, America \\
\hline Aglaonema commutatum & South Asia \\
\hline Zantedeschia aethiopica & South Africa \\
\hline Opuntia bigelovii & North and South America \\
\hline Púnica granatum & South Africa \\
\hline Gasteria verrucosa Haw. & South Africa \\
\hline Haworthia truncata & South Africa \\
\hline Setcreasea purpurea & Mexico \\
\hline Tradescantia spathacea Sw & Tropical forests of Florida \\
\hline Ruscus hypophyllum & Asia, the Mediterranean \\
\hline Callistemon citrinus & Australia \\
\hline Euphorbia milii & Tropics and subtropics \\
\hline Codiaeum variegatum & Asia \\
\hline Caesalpinia pulcherrima & West Europe \\
\hline Jacobinia pohliana & Tropical forests of Brazil \\
\hline Tradescantia blossfeldiana & Argentina \\
\hline Tradescantia virginiana & Argentina \\
\hline Cereus peruvianus & Central and North America \\
\hline Cordyline terminalis & Asia, America, Australia \\
\hline Monstera obliqua & Tropics of Africa \\
\hline Bryophyllum manginii & Central Madagascar \\
\hline Kalanchoe blossfeldiana & Australia, Africa, America \\
\hline Callīsia frāgrans & Mexico, America \\
\hline Soleirolia Gaud & Tropical regions \\
\hline Vallota speciosa & Subtropics of South Africa \\
\hline Impatiens walleriana & Subtropics \\
\hline Spathiphyllum floribundum & South America, East Asia \\
\hline Vitis amurensis & Western and Eastern Hemisphere \\
\hline Vitis vinifera & Central Asia \\
\hline Vitis vulpina & America \\
\hline Tecoma & Tropics and subtropics \\
\hline
\end{tabular}

Figure 4. A sketch of the recommended plant placement in the winter garden.

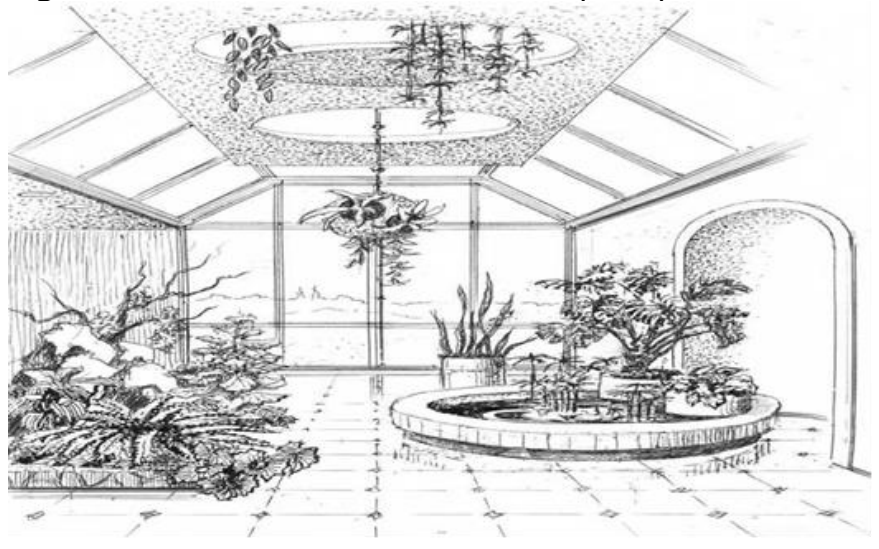


Table 3. Distribution of greenhouse plants by the climatic zones.

\begin{tabular}{|c|c|}
\hline $\begin{array}{l}\text { Name of the group } \\
\text { of plants } \\
\text { depending on the } \\
\text { natural habitats }\end{array}$ & Names of genera (in Latin) \\
\hline Tropical plants & $\begin{array}{l}\text { Abutilon, Hibiscus, Aloe, Plectranthus, Zephyranthes, Sansevieria, Cattleya, Pilea Lindl, Musa, } \\
\text { Peperomia, Colocasia, Persea, Euphorbia, Cordyline, Monstera, Helxine, Tecoma }\end{array}$ \\
\hline Subtropical plants & $\begin{array}{l}\text { Aspidistra, Asparagus, Begonia L., Diospyros, Sparmannia, Agave, Phoenix, Justicia, } \\
\text { Lamiales, Guzmania, Amaryllis, Coleus, Strelitzia, Ananas, Zantedeschia, Gasteria, Haworthia, } \\
\text { Bryophyllum, Kalanchoe, Vallota, Impatiens }\end{array}$ \\
\hline $\begin{array}{l}\text { Plants of } \\
\text { subtropics }\end{array}$ & Clivia, Echeveria \\
\hline $\begin{array}{l}\text { Plants of } \\
\text { Mediterranean }\end{array}$ & $\begin{array}{l}\text { Fortunella, Citrus, Buxus, Yucca, Dracaena, Philodendron, Ficus, Pelargonium L'Her, } \\
\text { Ligustrum, Rosmarinus, Vinca, Laurus, Tradescantia, Taxodium, Rosa, Billbergia, Vriesea, } \\
\text { Nerium, Opuntia, Setcreasea, Tradescantia, Callistemon, Caesalpinia, Jacobinia, Tradescantia, } \\
\text { Cereus, Callisia, }\end{array}$ \\
\hline Plants of Asia & $\begin{array}{l}\text { Aucuba, Fatsia, Trachycarpus, Chlorophytum, Geranium, Nephrolepis, Hedera, Cryptomeria, } \\
\text { Paulownia, Radermachera, Crinum, Scindapsus, Ruellia, Aglaonema, Granátum, Ruscus, } \\
\text { Codiaeum, Spathiphyllum, Cissus }\end{array}$ \\
\hline
\end{tabular}

In our opinion, considering a great number of plant species with the natural area of origin in the Tropics, the site allocated exactly to this group of plants will be the most effective one in terms of how it looks like and what size it has. Despite the fact that the plants of Tropics continuously vegetate throughout the year, necessary conditions for the development of this group of plants should be thoroughly provided Kryzhanivska, 2015.

Figure 5. Trees and shrubs of the greenhouse.

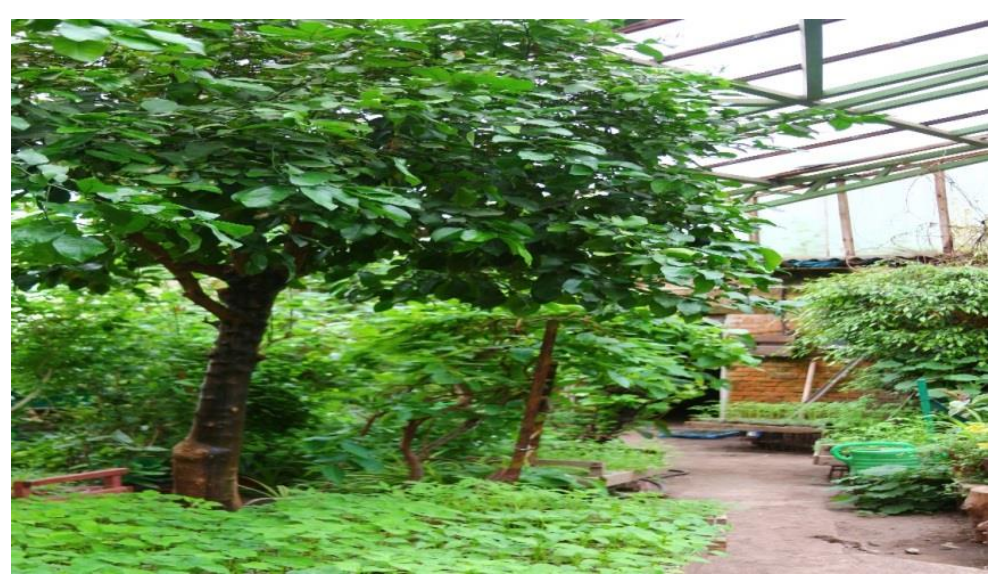

It is well-known that tropical plants are accustomed to the constantly high indoor temperature $\left(15-20^{\circ} \mathrm{C}\right)$, day and night equality and very high humidity (up to $90 \%$ ), which is the most important condition for their successful existence in our latitudes. If all the requirements are met, all the introduced plants beginning with palm trees and ferns and finishing with other tropical plants will flower or even bear fruit Kryzhanivska, 2015.

A garden having clearly "expressed seasons" is often called a subtropical winter garden. It is claimed that the spring season, which begins in February, is the most ornamental one and rich in plant flowering. From late October till late January, ornamentality of plants is low, compared to other seasons. After all, this is the period when the plants are dormant and the temperature in the winter garden should drop to $10-12^{\circ} \mathrm{C}$ Kryzhanivska, 2015. Therefore, it is advisable to have subtropical plants in the greenhouse, e.g. Alocasia, Areca, Acacia catechu, Dieffenbachia, Pandorea Sansevieria, Syngonium, etc., which will attract the visitors regardless of the season. Subtropical plants start to bloom actively in March, which greatly increases the number of the greenhouse visitors.

The most popular representatives of dry subtropics are succulents, plants characterized by the ability to accumulate a large amount of moisture and vital substances in their leaves. As for the requirements for the placement where the succulents grow, it should be hot in summer and it should be dry and cool in winter.

Analyzing the greenhouse assortment, it has been found that plants of dry subtropics are represented only by a few species, so the collection of succulents and cacti, representatives of which begin to bloom at the beginning of spring, must be replenished in the greenhouse. A great diversity of species also includes those that naturally live on volcanic rocks in semi-deserts. There can be created interesting compositions in the greenhouse in the form of succulent florariums (special devices made of glass or transparent plastic with floral compositions inside of them) or separate the area under the cactusarium that will represent a collection of cacti placed in the conditions that are similar to the natural habitat of these plants.

The choice of plants for the Mediterranean group is very wide, since most plants of this group normally grow and develop in cool gardens in winter. As for the spring period of their growth and development, they need heat and sun by the autumn. In winter, when many greenhouse plants experience a dormant period, they drop their leaves and require mandatory pruning. The requirements for the place where they grow during this period is that it should be light and cool [3].

Plants of Asia are not demanding, compared to the plants of other groups and they can grow in the greenhouse both in warm and cold winter time. The positive aspect is that they are not demanding to the maintenance. To grow and develop, it is enough to meet the temperature regimes. 
Due to some available properties like adaptability and environmental plasticity, plants that are naturally distributed in different parts of the Earth can be used to create various compositions in winter gardens or greenhouses. The choice of plants for the winter garden is wide.

\section{Conclusion}

The greenhouse of Podillia Botanical Garden includes 94 plant species that represent 88 genera and 44 families. Plants from different natural areas of origin are randomly arranged in the greenhouse without a certain order or systematization. It is recommended to divide all plants of the greenhouse into groups, to create so-called collections of tropical plants, subtropical plants, plants of dry Subtropics, plants of the Mediterranean and plants of Asia. Because of a small number of plants of dry Subtropics in the greenhouse of Podillia Botanical Gardens, the collection of succulents must be replenished, and a florarium and cactusarium must be established.

\section{References}

Monarkh, V.V. (2019). Biological and ecological characteristics of dendroflora of the Podillia botanical garden of Vinnytsia National Agrarian University. Collection of scientific works of VNAU "Agriculture and Forestry", 13: 228-238.

Cherniak, V.M., Prokopchuk, V. M., Monarkh, V. V. (2018). Some prospects of growing and use of China aster space greening in Podillia zone. Scientific Bulletin of NLTU of Ukraine, 28 (7): 22-26.

Kryzhanivska, N.Y. (2015). Fundamentals of Landscape Design: textbook. Kyiv: Lira-K.

Kucherivyi, V.P. (2017). Landscape Architecture: textbook. Lviv: Novyi Svit-2000.

Ermolova, E.V. Landscape Art: educational manual. Volgograd : In-Folio, 2010.

Roy V. (2019). Coniferous plants as the main decoration of the winter garden. Beauty and Benefits. A gardener's monthly workshop "Non-boring Garden", 1 (2): 14-17.

Monarkh, V.V., Pantsyreva, H.V. (2019). Stages of the Environmental Risk Assessment. in Ukraine. Ukrainian Journal of Ecology, 484-492.

Votinov, M.A. (2011). Summary of lectures on the course "Landscape Design". Kharkiv National Academy of Municipal Economy. Kharkiv: KNAME. 98 p.

Mazur, V.A., Pantsyreva, H.V., Mazur K.V., Monarkh, V.V. (2019). Ecological and biological evaluation of varietal resources Paeonia L. in Ukraine. Acta Biologica Sibirica, 5 (1): 141-146.

Neyko I., Yurkiv Z., Matusiak M., Kolchanova O. (2019). The current state and efficiency use of in situ and ex situ conservation units for seed harvesting in the central part of Ukraine. Folia Forestalia Polonica, Series A - Forestry. Vol. 61 (2), 146-155

\section{Citation:}

Monarkh, V.V., Matusiak, M.V. (2020). Analysis of plant assortment in the greenhouse complex of vinnytsia National Agrarian University as a key Component of student training. Ukrainian Journal of Ecology, 10(1), 192-198.

(cc) $\mathrm{EY}$ This work is licensed under a Creative Commons Attribution 4.0. License 